\title{
A STUDY ON THE LIFESTYLE OF SCHOOL-AGED CHILDREN IN PÄRNU CITY AND COUNTY
}

\author{
Monika Übner, Kandela Õun, Merle Mägi \\ Research Centre of Pärnu College, University of Tartu, Estonia
}

\begin{abstract}
In 2013/2014, a study on students' health behaviour was conducted in Estonia. In 2016, a school-aged children's lifestyle study was carried out in Pärnu City and Pärnu County. The survey explored the students' relations with their family and friends, family affluence, physical activity, use of alcohol, tobacco, and cannabis. 2,512 respondents participated in the study, $48 \%$ of them were boys and $52 \%$ girls. The respondents mainly had a family with two biological parents and their family financial status was mostly "good". About half of the respondents played computer games 0.5-3 hours a day, but those who were physically active spent less hours behind the computer and had higher family financial status. Respondents who were not physically very active met friends less frequently. In communication with friends, they used more social media. The questionnaire included several questions about risk behaviours. If the respondent had one bad habit, this was likely to lead to other bad habits, too.
\end{abstract}

Keywords: lifestyle; risk behaviour; school-aged children

\section{INTRODUCTION}

Every four years, the survey Health Behaviour of School-aged Children (HBSC) is conducted in most European countries. It provides a comprehensive overview of the health and well-being of school-age children [4]. This survey contains data about physical and mental health, excess weight and eating habits, physical activity, relationships with family and peers, school bullying, injuries and needed medical care, use of tobacco, alcohol and cannabis.

The survey of Estonian schoolchildren from 2013/2014 also gave trends from the previous survey [1]. One part of the data from this survey focused 
on risk behaviours. According to the study, 13\% of 15-year-old boys and 3\% of 15 -year-old girls smoked regularly. $5 \%$ of 11 to 15 -year-old children used an alcoholic drink at least once a week. In their lifetime, every $10^{\text {th }}$ of school-aged children had tried cannabis and, among 15-year-old children, every fourth had tried it.

Children's risk behaviour is related to family affluence and relations with parents and friends. Granado-Alcon et al. [3] found that the risk of drinking alcohol among schoolchildren is higher when they live in a single-mother home or live with mother and stepfather. In addition, the risk was higher when the relations with parents were poor. There were no gender differences. Abu-Bakar et al. [2] found that absence of mother, higher number of family members and single-parent families affect children's antisocial behaviour. The European study found that children from high-affluence families were most likely to report good relations and easy communication with parents [4]. Higher family affluence also relates to higher life satisfaction and physical activity. Children have different screens at home: TV, game consoles, smartphone, laptop with internet access, tablet, etc. Higher screen time is associated with lower affluence in Western Europe, but in some Eastern European countries, it is related to higher family affluence [4]. Sigman [5] recommended ideal screen time limits for 7-12 years $-1 \mathrm{~h}$; for $12-15$ years $-1.5 \mathrm{~h}$ and over 16 years $-2 \mathrm{~h}$ per day.

School-aged children's lifestyle in Pärnu City, Estonia, was previously studied in 2000, 2006 and 2011. In 2016, this survey was conducted in Pärnu City and Pärnu County. The aim of the survey was to obtain an overview how the youth in Pärnu live, what are their habits and attitudes, risk behaviours, and relationships with family, friends, and classmates. On this basis, it is better to plan prevention of risk behaviour and free-time activities projects for young people and longer-term activities. In the current article, we will consider only four health risk behaviours among schoolchildren: tobacco use, alcohol use, cannabis use and lack of physical activity. The results of that survey were compared with the Estonian HBSC study, which was carried out in 2014.

\section{MATERIAL AND METHODS}

The survey contained questions about the relations with family and friends, family affluence, physical activity, spending time by playing computer games, use of alcohol, tobacco, and cannabis. Multiple-choice questions and claimsbased questions were used. The respondents of the survey were schoolchildren from the $5^{\text {th }}$ to the $9^{\text {th }}$ forms. The size of the target group was 3,696 
schoolchildren in Pärnu City and County by the educational statistics portal www.haridussilm.ee.

The survey took place in the web application LimeSurvey and was done in school computer classes. The period of the survey was from 1 March to 15 May 2016. 1,773 respondents from Pärnu City and 739 from Pärnu County participated in the survey. It is $68 \%$ of the whole target group, which is sufficient for making general conclusions.

The Estonian HBSC study had 11-, 13- and 15-year-old children as its target group, so in the current study these data can compare with children from the $5^{\text {th }}, 7^{\text {th }}$ and $9^{\text {th }}$ forms. Statistical analysis was performed using the SPSS program, version 23.0. The results were presented in column charts which allow visual comparison by class and gender. The T-test and correlation analysis to study possible relations were also conducted and the results are presented in the text after figures.

\section{RESULTS AND DISCUSSION}

The total number of subjects was 2,512 (Table 1), $48 \%$ of them were boys and $52 \%$ were girls.

Table 1. Student membership by forms

\begin{tabular}{lcccccc}
\hline Forms & $\mathbf{5}$ & $\mathbf{6}$ & $\mathbf{7}$ & $\mathbf{8}$ & $\mathbf{9}$ & Total \\
\hline Number of respondents & 517 & 470 & 503 & 510 & 512 & 2512 \\
\hline $\begin{array}{l}\text { The proportion of the sample } \\
\begin{array}{l}\text { The number of schoolchildren of the } \\
\text { region }\end{array}\end{array}$ & $20.6 \%$ & $18.7 \%$ & $20.0 \%$ & $20.3 \%$ & $20.4 \%$ & $100 \%$ \\
\hline $\begin{array}{l}\text { The proportion of schoolchildren in } \\
\text { the class }\end{array}$ & 725 & 718 & 752 & 770 & 3696 \\
\hline
\end{tabular}

Source: www.haridussilm.ee

\section{Family affluence and relations with parents and friends}

Family life is the most important support for school-aged children. Relationships in the home is an important aspect. Today the concept of the family is indistinct. There are families with one parent but also with two homes and families, or the family with a foster parent, foster sisters and brothers. All these relationships affect children's everyday life at home and at school.

There were also families with a grandmother (14\%) or a grandfather $(7 \%)$ living with them. $65 \%$ of the respondents had a family with two parents 
(mother and father), 30\% live in a single-mother and 3\% in a single-father family. The Estonian HBSC study [1] found that the proportion of respondents with two biological parents was the same, but the proportion of respondents with one biological parent was much lower, 30\% in the current study and 19\% in the Estonian HBSC study [1]. The Estonian statistical database Population and Housing Census 2011 showed that the proportion of single-parent families with adolescents was much higher (34\%) when the children were between 12-17 years old [6]. The data from the current study confirmed these statistical data.

There were $17 \%$ of respondents without any siblings, $36 \%$ had one sibling. A quarter (25\%) of the respondents lived in a family with three children. 20\% of the respondents reported their parents' relationship less or more worrying. The respondents rated their family financial status mostly as "good" (4.02 on the 5-point Likert-type scale). The respondents from two-parent or two-newpartner families (i.e. both parents having new partners) rated their financial status as a little higher than average (4.1), from single-parent or one-newpartner families as a little less than average (3.8 and 3.9). There was also a slight difference between satisfaction with their life according to the family type - the respondents from families with two parents and families where both parents were in new relationship had the average 8.2 (10-point Likert-type scale), from single-parent families and from one-new-partner families - 7.6. Figure 1 presents the relationships with other people.

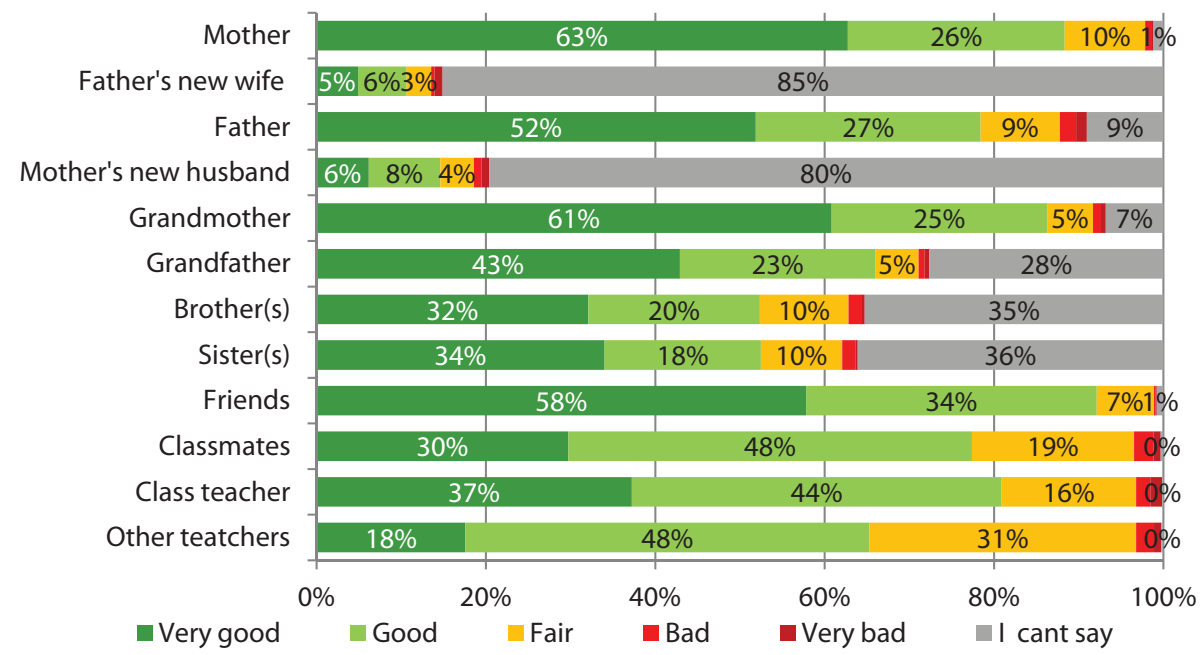

Figure 1. Respondents' estimates of their relationships with other people. 
The respondents had the best relationships with their mother, grandmother and friends. There were no differences between boys' and girls' assessments. There was no statistically significant correlation between relationship assessments and spending of time playing on electronical devices.

The respondents who played computer games on schooldays for four or more hours made up $21 \%$. The children who did not play computer games on schooldays at all constituted $17.6 \%$, and those who played $0.5-3$ hours $48.7 \%$. If the respondents physical activity was correlated to the hours playing computer games (see table 2), it was found that those who were physically more active spent less time playing computer games, but there was no significant correlation between these two characteristics, which is also due to the fact that the number of physically inactive respondents was low.

Table 2. Respondents' physical activity compared with the time of playing games on electronic devices

\begin{tabular}{|c|c|c|c|c|c|c|c|c|c|c|}
\hline & & \multicolumn{9}{|c|}{$\begin{array}{l}\text { How many hours a day do you usually play games on electronic } \\
\text { devices in your free time? }\end{array}$} \\
\hline & & Oh & $0.5 \mathrm{~h}$ & $1 \mathrm{~h}$ & $2 \mathrm{~h}$ & $3 h$ & $4 h$ & $5 \mathrm{~h}$ & $6 \mathrm{~h}$ & $7 \mathrm{~h}$ \\
\hline \multirow{8}{*}{$\begin{array}{l}\text { Report the } \\
\text { number of } \\
\text { days over the } \\
\text { past week } \\
\text { during which } \\
\text { you were } \\
\text { physically } \\
\text { active for a } \\
\text { total of at least } \\
60 \text { minutes. }\end{array}$} & 0 day & $18.8 \%$ & $6.3 \%$ & $6.3 \%$ & $17.2 \%$ & $10.9 \%$ & $4.7 \%$ & $7.8 \%$ & $4.7 \%$ & $23.4 \%$ \\
\hline & 1 day & $15.1 \%$ & $18.0 \%$ & $12.2 \%$ & $12.9 \%$ & $11.5 \%$ & $10.1 \%$ & $3.6 \%$ & $3.6 \%$ & $12.9 \%$ \\
\hline & 2 days & $19.0 \%$ & $13.5 \%$ & $17.6 \%$ & $13.5 \%$ & $13.5 \%$ & $9.0 \%$ & $4.8 \%$ & $3.1 \%$ & $5.9 \%$ \\
\hline & 3 days & $17.7 \%$ & $17.7 \%$ & $13.1 \%$ & $16.7 \%$ & $11.9 \%$ & $8.7 \%$ & $5.8 \%$ & $3.9 \%$ & $4.4 \%$ \\
\hline & 4 days & $19.4 \%$ & $16.4 \%$ & $15.9 \%$ & $14.4 \%$ & $15.3 \%$ & $10.3 \%$ & $4.1 \%$ & $1.3 \%$ & $2.8 \%$ \\
\hline & 5 days & $16.4 \%$ & $15.7 \%$ & $16.4 \%$ & $17.5 \%$ & $13.8 \%$ & $8.8 \%$ & $5.3 \%$ & $3.0 \%$ & $3.2 \%$ \\
\hline & 6 days & $14.8 \%$ & $23.6 \%$ & $19.7 \%$ & $20.7 \%$ & $8.9 \%$ & $7.9 \%$ & $2.0 \%$ & $1.5 \%$ & $1.0 \%$ \\
\hline & 7 days & $17.5 \%$ & $16.6 \%$ & $15.6 \%$ & $18.5 \%$ & $12.1 \%$ & $6.2 \%$ & $6.0 \%$ & $2.9 \%$ & $4.5 \%$ \\
\hline
\end{tabular}

The relations between the respondents' physical activity and the frequency of interaction with friends showed that these respondents who were not physically very active also met friends less frequently. However, playing with digital devices for less than four hours a day did not affect their face-to-face communication with friends. If they were playing games for longer than four hours, the effect was noticeable.

Nowadays, digitization is an inevitable phenomenon, and the use of technologies in daily life is taking an increasingly larger part, leaving the direct contact to the background. Every day, 36\% of the respondents talk with their friends on the phone or Internet directly, 55\% interact with messages in social media and $30 \%$ of the respondents like to meet their friends face-to-face 
(Figure 2). The same was found in the Estonian HBSC study [1]. School-age children used social media in communication with friends more frequently than any other medium.

\section{How often do you ... \\ ... talk with your friends by phone or over the Internet directly through such programs as Skype \\ ....interact with your friends messaging in social media and a wall post on Facebook, Twitter, some other apps (such as Instagram, etc) \\ ... meet your friends after school hours face to face}

not at all or rarely

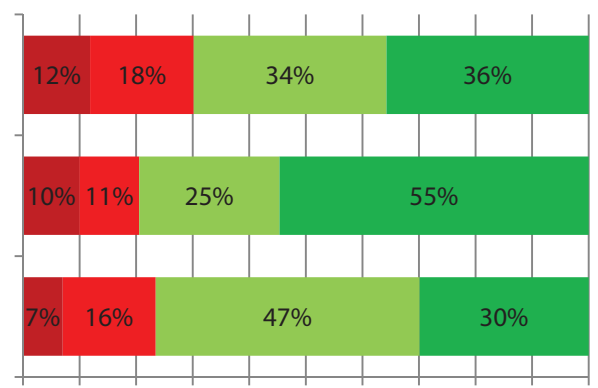

0\% 10\% 20\% 30\% 40\% 50\% 60\% 70\% 80\% 90\% 100\%

$$
\text { very week } \quad \text { Every week Every day }
$$

Figure 2. Communication with friends.

\section{Physical activity}

Children were asked how many days in the past week had they been physically active for at least one hour. WHO guidelines [7] state that children aged 5-17 should participate for at least 60 minutes in moderato-vigorous physical activity daily. The current study revealed that $20 \%$ of the respondents reported themselves being that active. The most active in their own words were the $8^{\text {th }}$-form boys (28\%) (Figure 3). $2.5 \%$ of the respondents were not physically active at all, and the least active were the $6^{\text {th }}$-form boys $-9 \%$ of them had not been physically active in the last week.

A direct link was revealed between economic prosperity and physical activity. The respondents who estimated their family financial status as high were physically more active for all days of the week, $6 \%$ of all respondents (Table 3). The lower the family financial status, the smaller was the children's physical activity. This may be caused by insufficient resources for attending various training sessions. The same result was found in the Estonian HBSC study - school-age children were physically more active when the family income was higher [1]. 


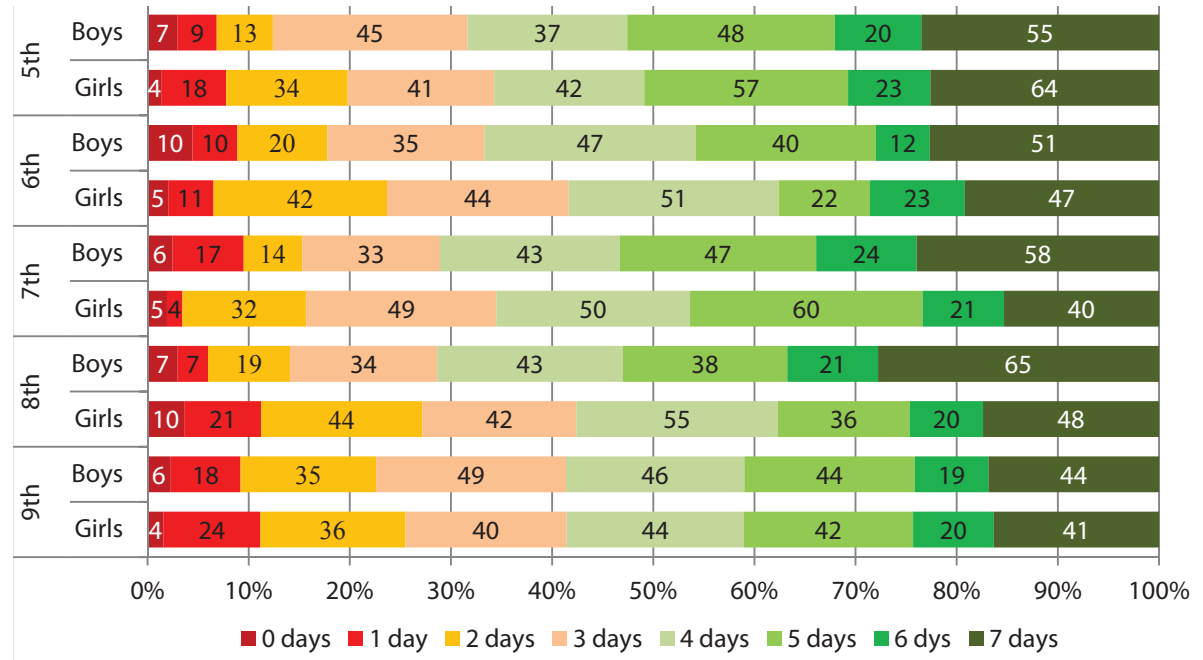

Figure 3. Physical activity of respondents in both genders and all classes

Table 3. Respondents' physical activity compared with the family financial status.

\begin{tabular}{lcccccc}
\hline & \multicolumn{5}{c}{ How do you estimate your family financial status? } \\
\cline { 2 - 7 } & & High & Good & We can manage & Not so good & We are poor \\
\hline How many & 0 day & $18.8 \%$ & $42.2 \%$ & $35.9 \%$ & $1,6 \%$ & $1.6 \%$ \\
\cline { 2 - 7 } $\begin{array}{l}\text { days in the } \\
\text { past week } \\
\text { have you been } \\
\text { physically active } \\
\text { for at least one } \\
\text { hour? }\end{array}$ & 1 day & $18.0 \%$ & $47.5 \%$ & $30.9 \%$ & $2.9 \%$ & $0.7 \%$ \\
\cline { 2 - 7 } & 2 days & $18.7 \%$ & $49.8 \%$ & $29.4 \%$ & $1.7 \%$ & $0.3 \%$ \\
\cline { 2 - 7 } & 4 days & $18.9 \%$ & $58.0 \%$ & $21.8 \%$ & $1.2 \%$ & $0 \%$ \\
\cline { 2 - 7 } & $20.5 \%$ & $57.0 \%$ & $20.5 \%$ & $1.5 \%$ & $0.4 \%$ \\
\cline { 2 - 7 } & 6 days & $22.4 \%$ & $55.8 \%$ & $21.2 \%$ & $0.5 \%$ & $0.2 \%$ \\
\hline
\end{tabular}

In addition, children who were physically more active were more satisfied with their life (Figure 4 ). Figure 4 shows that the $5-7^{\text {th }}$ grade students' life satisfaction was more affected by physical activity than that of the $8^{\text {th }}$ and $9^{\text {th }}$ grade students. There can be effects of school requirements or age-related peculiarities. Completing the $9^{\text {th }}$ grade is the first big step for students to decide about their future life, and good grades on the school-leaving certificate are very important. At the age of 15-16, the adolescence period is beginning, and at this time satisfaction with life is affected by different aspects. 


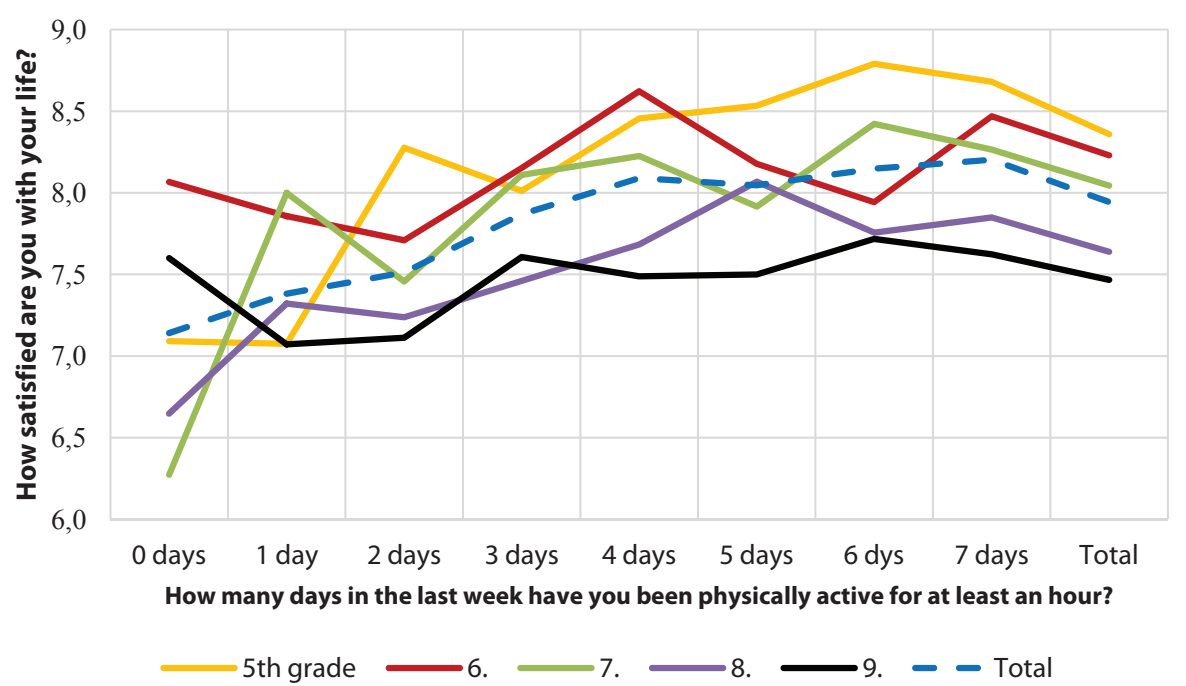

Figure 4. Satisfaction with life (10-point Likert-type scale) in different classes and in respondents with different physical activity.

\section{Use of tobacco, alcohol and cannabis}

In the survey, there were several questions about smoking cigarettes, e-cigarettes and the waterpipe. The correlation analysis showed that the respondents who smoked more cigarettes were also smoking e-cigarettes $(\mathrm{r}=0.58)$, the waterpipe $(\mathrm{r}=0.47)$ and often using snus $(\mathrm{r}=0.39)$. They were also drinking more alcohol $(\mathrm{r}=0.45)$ and using cannabis $(\mathrm{r}=0.50)$. Therefore, it can be concluded that if the respondent had one bad habit, it led to other bad habits, too.

Alcohol consumption among young people is a big problem. It is positive that the number of respondents who had drunk alcohol in the last 30 days was much smaller than of those who had used it in their lifetime (Figure 5). Therefore, we may expect that most of them have only tried alcohol or consume it very rarely. Regarding to tobacco products, consumption is similar to the national average [1]. Tobacco products have become replaced by the waterpipe, snus and e-cigarettes. When comparing these data to the previous Estonian HBSC study [1], the results were much lower. In the case of cannabis use it may be said that $10 \%$ of boys and $6 \%$ of girls had used it, but in the last 30 days, cannabis use was lower $-4 \%$ of the boys and $2 \%$ of the girls had used it. 


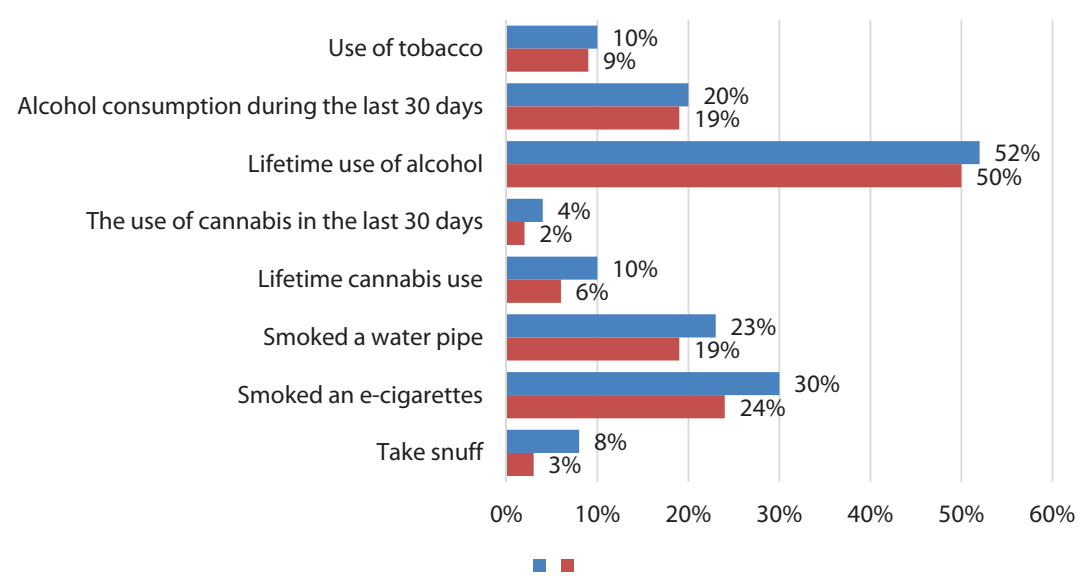

Figure 5. Use of tobacco, alcohol, cannabis, waterpipe, e-cigarettes and snus by both genders.

The respondents from the younger forms consumed alcohol or smoked to a rather limited extent (Figure 6). Consumption of cannabis is mentioned from the $7^{\text {th }}$ form. In the $9^{\text {th }}$ form, consumption of alcohol is also very common. Cannabis has been tried by $23 \%$ of the respondents, but cannabis use in the last 30 days is much lower.
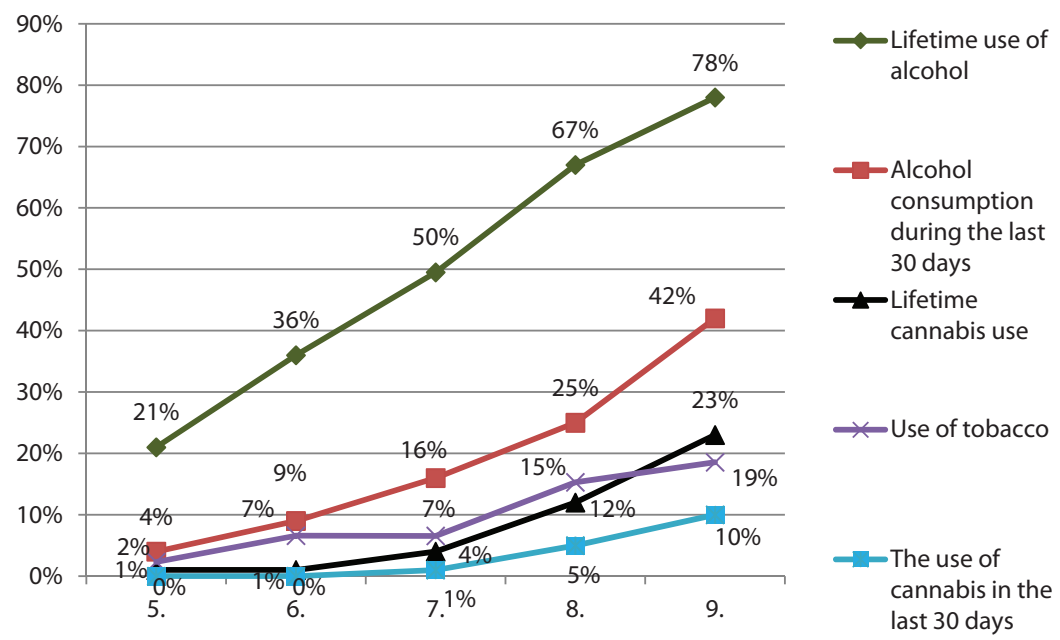

Figure 6. Use of tobacco, alcohol and cannabis in different forms. 


\section{CONCLUSION}

School-aged children in Pärnu City and County mainly live with their biological parents. However, there are more single-parent families than it was revealed in the previous Estonian HBSC study. Respondents' families have mostly good financial status and, therefore, they have more opportunities to participate in different sports. If children are physically more active, they have less time for playing computer games. School-aged children prefer communicating with friends through social media to face-to-face communication. Lifetime use of alcohol, tobacco and cannabis is growing with age. Many children have tried these mostly once. More problematic is the use of alcohol in the $9^{\text {th }}$ grade where $42 \%$ of the respondents had used it in the past 30 days. It was also found that if the respondent used alcohol too often, then he/she also used tobacco and cannabis.

\section{REFERENCES}

1. Aasvee K., Liiv K., Eha M., Oja L., Härm T., Streimann K. (2016). Eesti kooliõpilaste tervisekäitumine. 2013/2014. õppeaasta uuringu raport. Tallinn: Tervise Arengu Instituut.

2. Abu-Bakar S.H., Wahab H.A., Islam, M.R. (2016). Parental attachment for atrisk children's antisocial behaviour: A case of Malaysia. Child Care in Practice, 22(2), 148-165.

3. Granado-Alcon M.C., Pedersen J.M., Carrasco-Gonzalez A.M. (2002). Greenlandic family structure and communication with parents: Influence on schoolchildren's drinking behaviour. Int J Circumpolar Health, 61(4), 319-331.

4. Inchley J., Currie D., Young T., Samdal O., Torsheim T., Augustson L., Mathison F., Aleman-Diaz A., Molcho M., Weber M., Barnekow V. (2016). Growing up unequal: gender and socioeconomic differences in young people's health and well-being. Health Behaviour in School-aged Children (HBSC) study: international report from the 2013/2014 survey. Copenhagen: WHO Regional Office for Europe.

5. Sigman A. (2012) Time for a view on screen time. Arch Dis Child, 97(11), 935-942.

6. Tõnurist A. (2014). Üksikvanematest Eestis. [Single parents in Estonia]. Retrieved from https://statistikaamet.wordpress.com/tag/uksikvanemad-eestis/

7. World Health Organization. (2010). Global Recommendations on Physical Activity for Health. Geneva: WHO Press.

\section{Address for correspondence:}

Monika Übner

Pärnu College, University of Tartu

e-mail: monika.ubner@ut.ee
Kandela Õun

Pärnu College, University of Tartu

e-mail: kandela.oun@ut.ee 